\author{
Bożena Tokarz (D) \\ Uniwersytet Śląski \\ tokarzbozena@gmail.com
}

\title{
Przekład w perspektywie awangardowości
}

Awangardowość oznacza ten rodzaj prekursorstwa, który poprzedza jakąś zasadniczą zmianę części lub całości paradygmatu kulturowego. Przekład może taką zmianę sprowokować w literaturze przyjmującej, prezentując utwory mające potencjał dokonania w niej zwrotu, albo może stać się przewrotem w sztuce tłumaczenia. Może to nastąpić dzięki wyborowi równolegle rozwijającej się obcej literatury awangardowej, choć rola awangardowa przekładu zależy bardziej od potrzeb i momentu rozwojowego literatury rodzimej tłumacza. W przekładzie ujawnia się ona na trzy sposoby: dotyczy przekładu tekstów awangardowych i ich odkrywczej funkcji w literaturze przyjmującej, tekstów należących do porządku historycznoliterackiego - awangardy historycznej oraz krytycznego stosunku do przekładu wyrażanego zwykle przez odrzucenie ekwiwalencji werbalnej i znaczeniowej.

Uznając przekład artystyczny za tekst werbalny i związany [Barańczak 1974: 47-74] ${ }^{1}$, powstały w wyniku przeniesienia sensu wyrażonego w innym języku werbalnym, można zauważyć, że zjawisko awangardowości plasuje się na płaszczyźnie procesu historycznoliterackiego oraz w sferze działań artystycznych zmierzających do zmiany istniejącego

Autor terminu. 
modelu literatury i związanej z tym wrażliwości. Te dwie płaszczyzny mogą się przenikać w zależności od dystansu czasowego dzielącego oryginał od jego tłumaczenia. Tłumacz może przyczynić się do powstania nowej doktryny estetycznej, kierunku lub nurtu, sięgając zarówno do utworu utrwalonego już w procesie literackim oryginału, jak i do bieżącej twórczości obcej, pod warunkiem że stanowi ona ważny głos w procesie zmian artystycznych i społecznych, którego nie dostrzega we własnej literaturze. Awangardowość w przekładzie należy więc rozumieć w aspekcie historycznoliterackim jako tłumaczenie utworów należących do awangardy historycznej oraz w aspekcie estetycznym wtedy, gdy przekład może spełniać funkcję awangardową, zmieniając oblicze literatury przyjmującej przez zapoczątkowanie nowego nurtu, a także przez odkrycie odmiennej wrażliwości, przy czym w literaturze wyjściowej lub w powszechnej nie musi być tak nacechowany [MOaP 1999]. Aspekt historycznoliteracki i estetyczny łączą się często, gdy przekład pełni funkcję awangardową. Zdarza się też tak, jak miało to miejsce w przypadku tłumaczenia Strefy Guillaume'a Apollinaire'a przez Adama Ważyka, że obcy utwór awangardowy stał się punktem wyjścia jednego z nurtów polskiej awangardy historycznej (w tym przypadku kubizmu poetyckiego), wpisując się jednocześnie w estetykę awangardową [Tokarz 2002: 115-128]. Zważywszy że w znacznym stopniu celem przekładu jest odkrywczość i otwarcie na siebie i innego, awangardowość tkwi w nim potencjalnie. Przekład bowiem nie tylko pełni funkcję mediacyjną i poznawczą dzięki dawaniu świadectwa, lecz w wielu przypadkach funkcję awangardową, przyczyniając się do zmiany wrażliwości twórczej i odbiorczej, a także - co jest oczywiste - do negacji zastanego modelu literatury zgodnie z zasadami ewolucji literatury, zmiennością i skokowością. W perspektywę awangardową wpisuje się dzięki funkcji, jaką spełnia w literaturze i w kulturze docelowej. Zgodnie z założeniami teorii wielosystemowej [Even-Zohar 2009: 197-203] ma on szansę zająć w niej pozycję centralną, przyczyniając się wraz z innymi zachodzącymi w niej zjawiskami do ustalenia nowych norm estetycznych, jak to miało miejsce w literaturze polskiej w przypadku Strefy Apollinaire'a czy prozy iberoamerykańskiej w latach siedemdziesiątych ${ }^{2}$. Sytuacja taka jest uzależniona od rozwoju procesu

2 Odrębne zjawisko, które zostanie w moich rozważaniach pominięte, stanowią eksperymenty poetów-tłumaczy i tłumaczy przekraczających przestrzeń werbalną przekładu w procesie szyfrowania i przekodowania. 
historycznoliterackiego literatury docelowej, świadomości artystycznej jej twórców oraz potrzeb i świadomości estetycznej odbiorców. Efekty artystyczne wynikające $\mathrm{z}$ uplasowania się przekładu w centrum zależą również od gotowości odbiorcy na przyjęcie zmian, a także od interakcji między literaturą a innymi sztukami oraz mediami. O jego awangardowej funkcji decyduje wartość wykonania, czyli tłumacz, potrzeby procesu historycznoliterackiego i oczekiwania odbiorcy.

Twórców awangardowych, a także wielu thumaczy wyróżnia postawa poszukująca oraz chęć zmiany istniejącej rzeczywistości estetycznej w kontekście kulturowo-społecznym. Ich siła sprawcza zależy bardzo często od szerszego kontekstu. Swoje decyzje podejmują nie tylko ze względu na własne potrzeby, lecz także w zależności od przygotowania i oczekiwań odbiorców - respektują je w różnym stopniu, ponieważ znane są sytuacje odrzucenia i odkrycia po latach autorów dzieł prekursorskich bądź przekładów, które pojawiły się za wcześnie. Działania awangardowe wynikają najczęściej z rozdźwięku między ikonosferą i powstającą na jej bazie psychosferą a ekspresją artystyczną. Sugestywnie opisał ten związek Aleksander Wat, wspominając atmosferę powstania Nowej Sztuki na początku XX wieku:

Moje pokolenie, to znaczy mnie podobnych [...], miało [...] poczucie katastrofizmu. Ale przed nami [...] było walenie się, ruiny, à la longue wesołe ruiny, rozumiesz, przedmiot do wesela duchowego, bo tu można właśnie coś nowego zbudować, to jest wielka niewiadoma, podróż w niewiadome, wielkie nadzieje, że z tego, z tych ruin właśnie... [...] Była to radość, że wszystko wolno. I w tym znaczeniu może nawet słowo futuryzm ma pewien sens [...]. Starczyło jedno hasło, jedno małe odkrycie, jedno zdanie składające się z trzech wyrazów: „słowa na wolności”. Rozumiesz, to hasło, że słowa mogą być na wolności, że słowa są rzeczą, że można z nimi robić, co się żywnie komu podoba, to była jedna olbrzymia rewolucja jak - powiedzmy - Nietzschego: Bóg umart. Bo nagle słowa są na wolności, można z nimi wszystko robić. I to dało nam niesłychaną dynamikę [Wat 1990: 26-27].

$\mathrm{Z}$ tego napięcia szczególnie silnie korzystała sztuka XX wieku, rozwijająca się eksplozywnie na początku tego stulecia. Jej dalsze dzieje wydają się proroczo skondensowane w twórczości niektórych artystów i nurtów awangardowych. Kierunki malarstwa zdają się wyznaczać dzieła Marcela Duchampa, Kazimierza Malewicza (wraz z nihilizmem Białego na białym), Władysława Strzemińskiego, a także Marca Chagalla; architektury 
- projekty urbanistyczne Le Corbusiera (Charles'a-Édouarda Jeannereta-Grisa); sztuki użytkowej - środowisko Bauhausu, teatru - Wielka Reforma Teatralna z Konstantinem Stanisławskim, Jewgienijem Wachtangowem, Wsiewołodem Meyerholdem, Edwardem Gordonem Craigiem, Erwinem Piscatorem, a także teorią Witkacego, wyrażoną w tekstach teoretycznych i dramatach; poezji - wiersze Walta Whitmana, futuryzmu, konstruktywizmu, ekspresjonizmu i nadrealizmu; prozy - utwory Marcela Prousta, François Mauriaca, Virginii Woolf, Jamesa Joyce'a, Gustave'a Flauberta, Witolda Gombrowicza. Idee światopoglądowe, społeczne, kulturowe, artystyczne i estetyczne obecne w ich utworach, nawet jeżeli stanowiły zamknięte propozycje, ujawniały też swe przeciwne oblicza. Słoweński poeta awangardowy Srečko Kosovel, zapowiadając późniejszą poezję, określał to zjawisko koniecznością paradoksu. Pisał:

Sploh „biti logičen” je strašno težko. Ali ste že kdaj poizkusili? Jaz že in takrat sem spoznal dvojno: svojo logiko, ki je radikalno konsekwentna in življenjsko logiko, ki je nelogična. Tako sem postal paradoksen. To je zame zelo važno. Kajti paradoks je naši dobi praktičnega razuma to, kar je nevihtni ogenj napram ognju na ognjišču. [...] To se pravi: Bodi paradoksen! [Kosovel 1977: 399] $]^{3}$.

Dzięki myśleniu zgodnie z logiką sprzeczności artysta może oddziaływać na rzeczywistość artystyczną i społeczną, ponieważ - jak w innym miejscu pisał Kosovel - „Umetnik mora biti kakor antena, ki sprejema najdaljnejše slutnje iz kozmosa, kipar, ki oblikuje iz sebe obraz bodočnosti" [ibidem: 95$]^{4}$.

Kosovel był twórcą awangardowym, lecz świadomość słoweńska lat dwudziestych i lat następnych XX wieku pozostawiała wiele do życzenia, co może wyjaśniać niedostateczną obecnością w języku słoweńskim tłumaczeń znaczących utworów awangardowych, w tym polskiej poezji,

3 „«Być całkowicie logicznym» jest strasznie ciężko. Czy już kiedyś próbowaliście? Ja już i wtedy rozumiałem podwójnie: dzięki własnej logice, która jest radykalna, konsekwentna, i dzięki logice życiowej, która jest nielogiczna. Tak stałem się paradoksalny. To jest bardzo ważne, ponieważ tak paradoksalny jest sposób dojścia do praktycznego myślenia, jak ogień pioruna wobec ogniska. [...] To znaczy: bądź paradoksalny!" [Kosovel 1977: 399, tłum. moje - B.T.].

4 „Artysta musi być jak antena, która odbiera najdalsze sygnały z kosmosu, jak rzeźbiarz, który z siebie wydobywa oblicze przyszłości” [Kosovel 1977: 95, thum. moje - B.T.]. 
prozy i dramatu należących do awangardy artystycznej i historycznej zarówno w porządku synchronicznym, jak i diachronicznym. Dotkliwym pominięciem jest skromna obecność poezji i refleksji teoretycznej: Tadeusza Peipera, Juliana Przybosia, Jana Brzękowskiego, Jalu Kurka, Adama Ważyka, a także Józefa Czechowicza. Nieco lepiej w perspektywie diachronicznej wygląda obecność w świadomości słoweńskiej polskiej prozy awangardowej Brunona Schulza, Witolda Gombrowicza i Witkacego jako autora dramatów i powieści. Ich twórczość w drugiej połowie XX wieku przybliżyli odbiorcy słoweńskiemu: Katarina Šalamun-Biedrzycka przekładem powieści Gombrowicza Ferdydurke w 1974 roku, Pornografi (Pornografija) w 1987 i prozy Brunona Schulza Sklepy cynamonowe (Cimetove prodajalne: izbrano delo) w 1990 roku$^{5}$; Nikolaj Jež, tłumacząc Witkacego Pożegnanie jesieni (Slovo od jeseni) w 1994, Gombrowicza Trans-Atlantyk w 1998 i Kosmos (Kozmos) wspólnie z żoną Karmen Kendą-Jež w 2007 roku, a Mladen Pavičič - wyborem z dzienników Gombrowicza pt. Dnevnik - w 1998 roku6. Dramat Gombrowicza Iwona, księżniczka Burgunda (Iwona, princesa Burgundije) przetłumaczył dla potrzeb teatru w Lublanie Igor Lampert (1991, Mestno gledališče ljubljansko), natomiast Nikolaj Jež - Ślub (Poroka, 2004, Slovensko mladinsko gledališče). Również dramat Witkacego znalazł swoje miejsce w słoweńskim życiu literackim i teatralnym za sprawą utworu Szewcy. Nowa sztuka ze ,śpiewkami” w trzech aktach - Čevljarji: znanstvena igra $v$ treh dejanjih $s$,,popevčicami”, który ukazał się w czasopiśmie „Dramatikon 1” w 1999 roku w przekładzie Darji Dominkuš i był wystawiany na scenach słoweńskich (m.in. w teatrze Dramsko gledališče v Novi Gorici w 1984 roku).

W tym zestawieniu przekładów prozy i dramatu należących do awangardy europejskiej zwraca uwagę rozpiętość czasowa między ich powstaniem - lata dwudzieste i trzydzieste ${ }^{7}$ - a thumaczeniami w latach 1974-2017. W okresie międzywojennym burzyły one zastane normy estetyczne, społeczne i kulturowe i były w znacznym stopniu niezrozumiałe również dla odbiorcy rodzimego. Pomimo że literatura polska w Słowenii

\footnotetext{
Jest to wybór z obu tomów opowiadań Schulza, z Sanatorium pod Klepsydra i Sklepów cynamonowych. W 2017 r. Jana Unuk z perspektywy drugiego tomu opowiadań przetłumaczyła opowiadania pisarza - Sanatorij Pri peščeni uri in drugi spisi. 6 Wcześniej w 1996 r. przekłady fragmentów z dzienników opublikowała w czasopiśmie „Nova revija” Jasmina Šuler-Galos.

7 Tę granicę czasową przekracza większość tłumaczonych utworów Gombrowicza.
} 
była tłumaczona od połowy XIX wieku, dzięki czemu uzupełniała świadomość artystyczną, to tłumacze, twórcy i czytelnicy słoweńscy (z jakiś przyczyn) nie dostrzegli specyficznie polskiego wkładu (nie było przekładów) w awangardę europejską. Nie znali polskiej awangardy lub byli niezainteresowani jej nowatorskimi doświadczeniami. Nie podjęli więc z jej tezami ani dialogu, ani polemiki, tak jak to miało miejsce w stosunku do awangardy serbskiej, chorwackiej czy zachodnioeuropejskiej [Vrečko 1986]. Nikolaj Jež twierdzi, że ,[...] słoweńska recepcja polskich utworów literackich, poza twórczością Mickiewicza, nie przyczyniła się do aktualizacji innowacyjnych lub rewolucyjnych poglądów, stanowiących o przełomie lub zapowiadających dążenia awangardowe nowych generacji” [Jež 2006: 68] ${ }^{8}$. Datująca się od 1856 roku ciągła w niej obecność literatury polskiej była poprzedzona trwającymi od pół wieku kontaktami słoweńsko-polskimi ${ }^{9}$, które ukształtowały „określone postawy charakterystyczne dla słoweńskiej recepcji polskich prądów kulturowych i literackich" [ibidem]. Pomijając niuanse tego zjawiska, należałoby wskazać na fakt, że w obiegu artystycznym brak tłumaczenia nie musi oznaczać braku znajomości obcej literatury przez twórców, szczególnie w przypadku języków blisko spokrewnionych, co nie zmienia faktu, że polska awangarda międzywojenna nie zaistniała kompleksowo w świadomości słoweńskiej.

Niedokończona lekcja z awangardy dała o sobie znać w rozwoju teatru, prozy i poezji, a także w odbiorze własnej poezji (Kosovel) i prozy (Vladimir Bartol) awangardowej. W konsekwencji Kosovela odkrył dla Europy i Słoweńców Marc Alyn w 1965 roku, nazywając swoje tłumaczenie adaptacją, a Bartola - Claude Vincenot w 1988. Tłumacze francuscy dostrzegli znaczenie ich twórczości nie tylko dzięki znajomości języka, lecz także w znacznym stopniu dzięki osobistym kontaktom z kulturą słoweńską. Stało się to podobnie jak z polską prozą i dramatem awangardowym w Słowenii, czyli w momencie gdy odkrycia awangardy już się upowszechniły. Alamut Bartola oraz Ferdydurke Gombrowicza odczytane zostały pragmatycznie i zawłaszczone przez polemikę polityczną. Oba

\footnotetext{
$8 \quad$ Poza sonetem Mickiewicza Rezygnacja przetłumaczonym przez France Prešerna na język niemiecki, Farys i trzy utwory z Sonetów krymskich ukazały się po słoweńsku dopiero w latach 1856 i 1857.

9 Pod koniec XVIII wieku Martin Kuralt przetłumaczył arię z Krakowiaków i górali Wojciecha Bogusławskiego, zapoczątkowując obecność literatury polskiej w Słowenii.
} 
utwory stały się politycznie aktualne, czego świadomość mieli zapewne tłumacze słoweński i francuski. W obu więc przypadkach mamy do czynienia z przekładami spóźnionymi, aktualnie wziętymi w użycie lub należącymi do przeszłości zamkniętej w porządku historycznoliterackim.

Przekład spóźniony w niewielkim stopniu stanowi drugie ,życie” oryginału, ponieważ nie wchodzi w przestrzeń innych tekstów literackich kultury przyjmującej czy decyzji autorskich. Zwykle nie uczestniczy w dialogu międzykulturowym. Wspomniani trzej polscy autorzy wykraczali poza swą epokę. Wielu badaczy uważa ich za prekursorów. Witkacy zapoczątkował $\mathrm{w}$ latach dwudziestych teatr absurdu $\mathrm{z}$ odcieniem metafizycznego okrucieństwa, czyli jeszcze przed traumatycznymi doświadczeniami II wojny światowej, i zmienił ideę spektaklu teatralnego, odrzucając mimesis. Antonin Artaud (Antoine Marie Joseph Artaud), aktor, twórca i teoretyk teatru francuskiego, należący od 1924 roku do ruchu surrealistycznego, był najbliższy w swojej teorii Witkacemu, chociaż nie wynikało to $\mathrm{z}$ wzajemnego oddziaływania. Twierdził, że teatr działa tak jak dżuma, metafizyka i okrucieństwo, przez co również odrzucał mimesis [Artaud 1978]. Doświadczenie teatru słoweńskiego nie objęło takiego myślenia o przedstawieniu, ponieważ w okresie międzywojennym nie istniały przekłady m.in. Witkacego czy Artauda. Teatr Ferda Delaka (Novi oder), działający wewnątrz ruchu awangardowego, wyrastał z konstruktywistyczno-lewicowych tendencji. Miał być komunikatywny i aktywny społecznie, lecz zakładał również obecność aktora jako biomechanicznego elementu spektaklu, co ostatecznie okazało się niezrealizowaną próbą. [Vrečko 1986: 238] Powstałe w 1927 roku z inicjatywy Delaka awangardowe czasopismo „Tank” stało się na krótki czas trybuną, gdzie wypowiadali się artyści nowej sztuki, a on sam przedstawiał swe założenia teatralne. Nie rozwiną jednak koncepcji aktora jako biochemicznego aspektu spektaklu. Ostatecznie skierował teatr na drogę realizmu i socrealizmu. Niemniej poszukiwania awangardowe artystów teatru szły w podobnym kierunku, sprzeciwu i sprzeczności, choć nie wchodziły ze sobą w dialog i kończyły się często na projekcie. Być może większa aktywność tłumaczy odkryłaby przed twórcami (nie tylko teatru) siłę paradoksu tkwiącego $\mathrm{w}$ grotesce. Formy groteskowe u Witkacego są wyrazem poszukiwania jedności istnienia (nie tylko wstrząsu) w obliczu niemotywowanej wielości; u Gombrowicza - wolności oznaczającej potencjalność i niegotowość oraz sprzeciw wobec wszelkim konwencjom; u Schulza - istoty istnienia świata i roli w nim człowieka (badacza i uzurpatora), któremu 
zagrażają niskie formy rzeczywistości. Odległość czasowa między ukazaniem się oryginałów a przekładów jest tak duża, że ich idee, a także realizacje stały się powszechne i nie może być mowy o równorzędnym dialogu ani o inspiracji. Ich tłumacze spełnili więc funkcję poznawczą, uzupełniając brakujące ogniwo rodzimego procesu historycznoliterackiego jako ambasadorzy literatury polskiej [Jarniewicz 2002] ${ }^{10}$.

Szczególną szansę podjęcia dialogu z kulturą słoweńską miała proza Brunona Schulza, ponieważ jej magiczna mitologizacja podszyta psychoanalizą Sigmunda Freuda wydaje się bliska wyobraźni słoweńskiej, co sugerować może m.in. proza Vlada Žabota. Polski pisarz widział w latach trzydziestych w micie i w magii możliwość zbliżenia się do istoty świata zgodnie z potrzebą niezwykłości u człowieka i niekiedy wbrew niemu. Tłumaczka niestety nie wydobyła całej niezwykłości tej prozy i może dlatego inna tłumaczka podjęła się tego zadania w 2017 roku, bogatsza o doświadczenie przekładów prozy iberoamerykańskiej na język słoweński.

$\mathrm{W}$ przypadku słabości ogniwa awangardowego w słoweńskim procesie historycznoliterackim przekłady, w tym z literatury polskiej, mogły spełnić funkcję awangardową we właściwym momencie historycznym. Nie spełniły, ponieważ powstały zbyt późno, plasując się na peryferiach w polisystemie literatury docelowej. Więcej, zaistniały w opozycji do rodzimej literatury awangardowej (Kosovel) także ze względu na odmienność polskiego modelu awangardowego [Tokarz 2004].

Przekłady spóźnione, bo tak je można nazwać z perspektywy kultury przyjmującej, również nawiązują dialog międzykulturowy. Jest to jednak dialog pośredni, w który potencjalnie wchodzą tłumacze jako wtajemniczeni oraz elitarni odbiorcy literatury tłumaczonej, ,znawcy” - jak nazwałby ich Janusz Sławiński. Mogą one stanowić jeden z komponentów jakiegoś początku, najczęściej jednak wzbogacają przestrzeń mentalną literatury przyjmującej. Przekład literatury awangardowej może nie być awangardowy w znaczeniu artystycznym i historycznym, jeżeli jest spóźniony lub pojawia się w niesprzyjającym mu czasie, choć wówczas ma szansę na późniejsze odkrycie przez odbiorców i twórców kultury przyjmującej. Tak się nie stało w odniesieniu do poezji polskiej najbliższej konstruktywizmowi, chociaż od 1947 roku język polski obecny jest na uniwersytecie w Lublanie, a Rozka Štefan, pierwsza lektorka języka polskiego i wybitna tłumaczka, stworzyła dobrą szkołę tłumaczy literatury

$\overline{10}$ Termin „ambasadorzy” zaczerpnęłam z artykułu Jerzego Jarniewicza. 
polskiej. Poeci Awangardy Krakowskiej zaproponowali doskonałą estetycznie i artystycznie formę poetycką [Lapiński 2002: 15-26] ${ }^{11}$, lecz ich twórczość nie wpisała się w historycznie ukształtowany słoweński model recepcji (oparty na poszukiwaniu podobieństwa $\mathrm{w}$ wartościach utrwalonych) oraz w wrażliwość artystyczną drugiej kultury. Zdaje się potwierdzać takie przypuszczenie niewielka liczba tłumaczonych wierszy poetów Nowej Fali związanych z tą tradycją, Stanisława Barańczaka [Tokarz 2016: 142-158] i Ryszarda Krynickiego, przy obfitości przekładów poezji Adama Zagajewskiego.

Idea, która przyświecała Awangardzie Krakowskiej, współgrała ze zmieniającą się ikonosferą i sposobem życia, z rozwojem środków technicznych i nauki, co prowadziło do przemian mentalnych, np. mechanizmów kojarzenia i związanej z nimi wyobraźni, a także wzajemnego oddziaływania na siebie różnych sztuk, najczęściej poezji i malarstwa. Różnorodność świata, wielość istnienia - jakby to określił Witkacy - zaprzeczała jednoznacznym rozwiązaniom, choć ta sama cywilizacja jednocześnie uniformizowała. Dostrzegali to również inni artyści, np. Apollinaire, który widział słowem, zafascynowany propozycjami malarskimi rodzeństwa Sonii i Roberta Delaunayów. Przyboś, również widzący słowem i uwrażliwiony na ruch, dał temu wyraz w poezji oraz $\mathrm{w}$ formule „sytuacji lirycznej”, nakładając na poetę obowiązek dostrzegania i tworzenia „sytuacji lirycznej”. Plastyczne widzenie Przybosia wyjaśnia jego poetycką aktywność w pracach łódzkiej grupy a.r. (artystów rewolucyjnych). Poeta miał być - według niego - odkrywcą nowej wrażliwości, zauważać zmiany ludzkiej psychiki [Przyboś 1955] ${ }^{12}$. Podobną świadomość mieli również inni artyści awangardowi. Poeci krakowscy wyrazili ją, stosując w praktyce i teorii zasadę skojarzeniową opartą na sprzecznościach i paradoksie w słowie poetyckim, w metaforze. Odczytanie jej sensu wymaga uruchomienia wielu werbalnych i obrazowych ścieżek skojarzeniowych. Dlatego pisali o poezji dla dwunastu, widząc w sobie apostołów nowej sztuki. Jednocześnie arystokratyzm estetyczny, pomimo przekonań raczej lewicujących, nie działał na rzecz ich popularności.

\footnotetext{
11 Autor zwraca uwagę na zjawisko intelektualne nowoczesności ukształtowane w kulturze polskiej przez szkołę lwowsko-warszawską, Awangardę Krakowską i konstruktywizm łódzki w kontekście poezji Juliana Przybosia.

12 Wcześniej Przyboś wyrażał się podobnie w wierszach, później przedstawił swoje stanowisko w tekstach teoretycznych.
} 
Srečko Kosovel, głosząc potrzebę paradoksu w poezji, również zmierzał do nadania poezji nowego kształtu (Ostri rimi), lecz za pośrednictwem potoczności i form gotowych (reklam, ogłoszeń, szyldów, instrukcji użycia itp.). Peiper natomiast zaproponował formę stylistyczną, metaforę, którą nazwał metaforą teraźniejszości, ponieważ zbudowana jest ona na słowach o odległych polach skojarzeniowych. Jest ekonomiczna (oszczędza użycie słów potrzebne do wyrażenia znaczenia, a także sensu). Nie nazywa, lecz pseudonimuje uczucia [Peiper 1972: 54-61] ${ }^{13}$, ponieważ ma odkrywać nieznane zachowania uczuciowe, czyli to, co Przyboś nazywał „sytuacją liryczną”, opartą na znaczeniu i obrazie. Do zasadniczej linii programowej w proponowanym modelu grupy Awangardy Krakowskiej, inspirowanej konstruktywizmem, należy dołączyć nadrealistyczne akcenty obecne w poezji Jana Brzękowskiego, związanego z francuską grupą Cercle et Carré, oraz żywiołowość futurystyczną Jalu Kurka.

Późniejsze dzieje poezji polskiej były silnie związane z tradycją Awangardy Krakowskiej jako jej kontynuacja albo negacja, a także Drugiej Awangardy, lubelsko-wileńskiej (Czechowicz, Miłosz), z katastrofizmem. Choć poezja Kosovela przez długie lata pozostawała nieznana szerszemu odbiorcy słoweńskiemu, ponieważ całość jego spuścizny została opublikowana dopiero 51 lat po jego śmierci [Tokarz 2004], to losy poezji polskiej i słoweńskiej związane są z samoświadomością poetycką, w kształtowaniu której awangarda historyczna (wraz z wszystkimi jej nurtami, a w Polsce szczególnie Awangarda Krakowska) odegrała ważną rolę, proponując podróż w niewiadome słowa i ludzkiej psychiki w nim zawartej. Opóźniona recepcja Kosovela, jak również brak przekładów Przybosia, Peipera, Brzękowskiego, Ważyka, Kurka, w których Kosovel odnalazłby rozum i serce w formule estetycznej (choć skierowanej do elitarnego odbiorcy), sprawiły, że poezja słoweńska późno zaczęła korzystać z doświadczenia awangardowego. W zasadzie wzmianki o nim (ze względu na niewielką ilość tekstów) pojawiły się dopiero w 1960 roku w przeglądzie Rozki Štefan Poljska književnost [Štefan 1960] oraz w 1963 w antologii pod redakcją i w tłumaczeniu Lojzego Krakara według wyboru dokonanego przez Ryszarda Matuszewskiego, Zygmunta Stoberskiego i Lojzego Krakara [1963]. W antologii znalazły się dwa wiersze Peipera (Z Górnego Ślaska i Upadek), mało reprezentatywne dla

13 Taki model poezji sformułował Tadeusz Peiper w 1922 r. w czasopiśmie „Zwrotnica”. 
jego modelu poezji, siedem wierszy Przybosia, jeden Ważyka, trzy wiersze Czechowicza oraz dwa Anatola Sterna, jeden Aleksandra Wata i fragment poematu Brunona Jasieńskiego Słowo o Jakubie Szeli. Pomimo że wymienieni poeci współtworzyli nowoczesną poezję, wybór nie daje obrazu artystycznego, mentalnego i estetycznego awangardy.

Natomiast w latach 1969-1999 spośród twórców Awangardy Krakowskiej przetłumaczono w Słowenii 17 wierszy rozproszonych $\mathrm{w}$ trzech antologiach (Alarm, Prošnja za srečne otoke i Veter davnih vrtnic) oraz w dwóch czasopismach („Dialogi” i „Planinski vestnik”). Większość przetłumaczyła lub zainicjowała ich przekład Rozka Štefan, uzupełniając miejsca nieznane odbiorcy słoweńskiemu w polskim procesie historycznoliterackim i jednocześnie brakujące $\mathrm{w}$ słoweńskim. W wyborze wierszy kierowała się ich wartością artystyczną, umiarkowaną postawą estetyczną (nie rewolucyjną), okazjonalnością (wiersz Triglav z tomu Przybosia Próba całości - 1961) [Planinski vestnik 1978: 771-772] i tematyką: patriotyczną i wolnościową (Przybosia Póki my żyjemy i Noc listopadowa z tomu Póki my żyjemy - 1944 oraz Na Wawel z tomu Rzut pionowy - 1952, Ważyka Gdzie świerk wysoki i Trzecia jesień z 1943, Kurka Pieśń o ojczyźnie z 1945 w przekładzie Pretnara) [Štefan i Jež, red. 1992] $]^{14}$ oraz miłosną (Przybosia Do ciebie o mnie z tomu Póki my żyjemy - 1944 i przedrukowany wiersz Ważyka Trzecia jesień) [Štefan, red. 1999: 84, 92]. Natomiast w czasopiśmie „Dialogi” pod antologijnym tytułem Iz poljske poezje obok Bolesława Leśmiana i Marii Pawlikowskiej-Jasnorzewskiej Rozka Štefan zaprezentowała w przekładzie Dušana Pirca (lektora języka polskiego w Uniwersytecie Jagiellońskim i thumacza) bardziej zróżnicowane i reprezentatywne wiersze Przybosia: Orzet i Notre Dame z Równania serca - 1938 oraz Noc powrotna z tomu Próba całości - 1961 i Kwiat nieznany z tomu Kwiat nieznany - 1968, uzupełniając w pewnym tylko stopniu wiedzę czytelnika rodzimego.

Jako pierwsza w Słowenii szerzej przedstawiła polską poezję awangardową Katarina Šalamun-Biedrzycka, badaczka awangardowej poezji słoweńskiej - Antona Podbevška i Antona Vodnika [Šalamun-Biedrzycka 1980]. W 1969 roku sięgnęła po kubistyczną poezję Adama Ważyka i opublikowała przekład czterech jego wierszy: Postój z tomu Semafory (1924) oraz Ars poetica, Próba i Tamto z tomu Wagon (1963) wraz

14 Wybór wierszy do antologii Alarm eksponuje polski patriotyzm i walkę narodowowyzwoleńczą. 
z rzetelnym komentarzem historycznoliterackim, w którym wyjaśniła ich awangardową wartość i funkcję, jak również kontrowersyjność postawy politycznej poety [Dialogi 1969: 264-266]. Tłumaczka, w pełni świadoma odkrywczości artystycznej Awangardy Krakowskiej, wprowadziła Ważyka w krąg dialogu poetyckiego w Słowenii, któremu najbliższy był w pewnym sensie w tamtym okresie jej brat, Tomaž Šalamun.

Wśród przekładów poezji polskiej awangardy historycznej najbardziej awangardowo został przedstawiony Adam Ważyk. Przy braku przekładów tekstów teoretycznych i poezji Tadeusza Peipera, wierszy Juliana Przybosia (z okresu międzywojennego począwszy od tomu Sponad), wierszy Jana Brzękowskiego zabarwionych nadrealistycznie, lecz zdyscyplinowanych mentalnie i międzywojennej poezji Jalu Kurka ${ }^{15}$, słoweński obraz polskiej awangardy historycznej jest znacząco zubożony. Nie tylko stanowiska badaczy, lecz także krytyczne wspomnienia Czesława Miłosza świadczą o znaczeniu awangardy w ówczesnym życiu literackim. Poetyka reprezentowana przez poszczególnych twórców, jak i całą grupę wywoływała nie tylko naśladownictwo, lecz także bunt artystyczny, m.in. żagarystów, wobec doskonałości estetycznej przy jednoczesnym marzeniu o tworzeniu wielkiej poezji [Miłosz 1982: 33-35; 1990: 122-136]. Z podobnego zwątpienia powstały wiersze Józefa Czechowicza jeszcze w latach dwudziestych, a więc wcześniej niż poetów wileńskich. Poezja i myśl teoretyczna Awangardy Krakowskiej wprowadziły mentalno-estetyczną zmianę wizji świata. Jako nurt awangardy historycznej twórczość grupy reprezentuje jednocześnie awangardę artystyczną, a ta, zmieniając artystyczne oblicze sztuki, zmienia sposób widzenia świata i możliwości jego rozumienia. Jej działania, środki i gesty nie mogą być powielane, lecz mają budzić zwątpienie, prowokować, zmuszając do poszukiwań sensu świata i człowieka. Niestety, jak pokazały dalsze dzieje poezji, ten precyzyjny model estetyczny okazał się nie tylko inspirujący, lecz także łatwy do naśladowania, przez co tracił swą kreatywność.

Skoro liczba i wybór wierszy polskiej awangardy historycznej są niewystarczające, by ich odbiorca miał wyobrażenie o polskiej awangardzie tamtego czasu, a proza awangardowa pojawiła się w Słowenii za późno, by uczestniczyć w słoweńskim życiu literackim, to przekłady literatury polskiej nie spełniały i nie spełniają funkcji awangardowej ani też nie

\footnotetext{
15 Zostały przetłumaczone tylko dwa jego wiersze, mało reprezentatywne dla jego poezji: Pieśń o ojczyźnie i Pochwała nart i śniegu.
} 
odzwierciedlają jej miejsca i roli w polskim procesie historycznoliterackim, nie mówiąc o uczestnictwie w przemianach artystycznych literatury rodzimej. Awangardowość w przekładzie nie jest więc kategorią zależną od oryginału, lecz od recepcji literatury obcej, niekoniecznie przekładowej.

Zarówno „znawcy”, czyli twórcy, tłumacze, badacze i krytycy, jak i czytelnicy i uczestnicy słoweńskiego życia kulturalnego posiadają pewną wiedzę o literaturze polskiej, ukształtowaną przez tradycję wzajemnych kontaktów. Śledzą i śledzili wydarzenia i fakty polskiego życia literackiego oraz prace literaturoznawcze i krytyczne ${ }^{16}$. Wzajemnej komunikacji służyło również pokonywanie bariery językowej w postaci takich inicjatyw, jak lektorat języka na uniwersytecie, studia i staże odbywane w Polsce czy radiowy kurs języka polskiego, prowadzony jeszcze przed II wojną światową [Vodnik 1963: 169-170]. Nie można więc sądzić, że zniekształcony obraz polskiej awangardy wynika wyłącznie z braku tłumaczeń i potrzebnej wiedzy odbiorczej. Komunikacja międzykulturowa na tym odcinku została zakłócona najprawdopodobniej z innych powodów. Sądzę, że jest ich kilka.

Przekład należy do systemu społecznego, jak twierdzi Teo Hermans - składa się z wielości aktów komunikacji, sam jest komunikacją opartą na współistnieniu przekazu, informacji i rozumienia. Komunikacja rozpoczyna się w momencie rozumienia, który określa przyjęcie jakiegoś punktu widzenia (indywidualnego i zbiorowego) [Hermans 2009: 297315]. W przypadku przekładu jest on uzależniony od kultury, sytuacji społecznej i gustu indywidualnego tłumacza. Przekład nie jest więc transferem, podobnie jak:

Komunikacja nie jest transferem, przenoszeniem istniejących wcześniej treści za pomocą medium, jakim jest język. W komunikacji mamy do czynienia $\mathrm{z}$ tym samym układem bodźców i inferencji, który leży u podstaw teorii relewancji. [...] inferencja otwiera przestrzeń do błędnego rozumienia. [...] błędne rozumienie jest ową pozorną niezgodnością pomiędzy znaczeniem zamierzonym i odebranym [...] [ibidem: 303$]$.

Manipuliści i badacze z kręgu „Translation Studies” zwrócili uwagę właśnie na ten aspekt komunikacyjny przekładu. Rozminięcie się

\footnotetext{
16 W słoweńskich przekładach $\mathrm{z}$ literatury polskiej ilustrują to rozbudowane parateksty.
} 
znaczenia zamierzonego (a nawet odebranego) w kulturze wyjściowej ze znaczeniem odebranym w kulturze przyjmującej zależy od: momentu rozwoju literatury przyjmującej, przyjętych w niej norm, jej miejsca w większym systemie literackim oraz od dodatkowych preferencji thumacza (gust, wrażliwość, wiedza, doświadczenie lekturowe itp.) ${ }^{17}$.

Patrząc $\mathrm{z}$ tej perspektywy na brak funkcji awangardowej w słoweńskich przekładach literatury polskiej, dostrzegamy różnicę między „hierarchiami ograniczeń" [Lefevere 2009: 223-246] w kulturze wyjściowej i kulturze przyjmującej, która jest odpowiedzialna za przyjęcie przekładu, a także, w tym przypadku, za jego brak. Dotyczy ona przyjmowanych norm literackich, językowych i kulturowych oraz stosunku do nich, a także związanych z nimi zachowań. Potrzebę zmiany normy poetyckiej odczuwał w pełni Kosovel jednocześnie z koniecznością zmian społecznych. Nie odważył się jednak na rewolucyjne artystycznie zmiany (choć uczestniczył w społeczno-politycznym ruchu słoweńskim organizacji Tiger) w granicach użycia słowa, zastępując je montażem i kolażem, zainspirowany poszukiwaniami malarzy, co po wielu latach stało się właśnie awangardowe wobec przeświadczenia o wyczerpaniu się możliwości słowa. Polscy poeci Awangardy Krakowskiej odwrotnie, słowo poddali analizie, denotując za pomocą „metafory teraźniejszości” nienazwane w standardowym języku zjawiska. Organizacją poetycką objęli przestrzeń semantyczną słowa i przestrzeń przez słowo ewokowaną, jej desygnat. Wskazali na nowe trajektorie mentalne, powstające w zmieniającym się cywilizacyjnie świecie, czyli na odmienne od dotychczasowych uczuciowość i rozumienie świata. To z kolei nie wytrzymało próby czasu, chociaż stało się podstawą poszukiwania sensu ,zmienionej skóry świata" [Peiper 1972: 27].

Werbalizowana rewolucyjność Antona Podbevška i Srečka Kosovela, historyczna i prekursorska w przypadku tego drugiego, była mniej lub bardziej połączona z lewicową działalnością społeczno-polityczną, z czynem [Vrečko 2011; Tokarz 2004]. Polscy awangardyści (nie tylko poeci sympatyzujący z lewicą) możliwość zmiany świata widzieli w kształtowaniu ludzkiej wrażliwości za pomocą przeżycia artystycznego i estetycznego (wyjątek stanowią poeci lewicy - Stanisław Ryszard Stande, Witold Wandurski, Władysław Broniewski - oraz futurysta Bruno

17 Por. teorię polisystemów Itamara Evena-Zohara, teorię refrakcji André Lefevere'a, a także kognitywistyczną teorię amalgamatów. 
Jasieński). Nie chcieli być inżynierami dusz, lecz uczyli patrzeć i rozumieć. Pokazywali wielość, względność oraz ograniczenia norm i konwencji, dlatego łamali również normy języka, czego słoweński odbiorca nie mógł zaakceptować ani wcześniej, ani obecnie. Społeczna i narodowa funkcja literatury i języka w kulturze słoweńskiej jest bowiem motywowana historycznie silniej niż w polskiej, ponieważ utratę niepodległości Polski poprzedzał czas rozkwitu i ciągłego jej rozwoju, kiedy literatura nie musiała pełnić roli zastępczej. Być może dlatego w okresie międzywojennym w Słowenii nie próbowano zintegrować polskiego modelu z własnym, okrywając go milczeniem. Wydaje się, że pozostał on nadal obcy Słoweńcom w zakresie poezji awangardy historycznej, której się nie tłumaczy nawet dla porządku historycznoliterackiego. Może wywoła jej obecność przekład wyboru wierszy i prozy Mirona Białoszewskiego z roku 2004 [Białoszewski 2004], ponieważ każdy system może przyjąć obcą poetykę na zasadzie integracji z własną, które to doświadczenie nie jest obce Słoweńcom, żyjącym w czworokącie kulturowym, włosko-niemiecko-węgiersko-chorwackim. Możliwości integracji z własnym modelem literackim znakomicie pokazali w tłumaczeniu innych tekstów Tone Pretnar i Nikolaj Jež, uczniowie i w pewnym sensie kontynuatorzy strategii thumaczeniowej Rozki Štefan.

Inspirująca - awangardowa - funkcja literatury polskiej w słoweńskim systemie literackim jest historycznie i artystycznie rozmyta, rzec by można: nieujawniona i wymagająca bardzo szczegółowych badań analitycznych. Na pewno taką funkcję pełniła poezja Adama Mickiewicza, jego Sonety i Konrad Wallenrod w stosunku do twórczości France Prešerna (Soneti nesrečije i Krst pri Savici) [Tokarz 2000: 261-270]. Stan ten wynika najprawdopodobniej z miejsca obu literatur w większym systemie literatur [Even-Zohar 2009: 197-203], a także sytuacji społeczno-politycznej. Nierównorzędne miejsce literatury słoweńskiej wobec polskiej kierowało uwagę artystów ku siłom o większej mocy. Lublańscy twórcy, a na pewno Kosovel, jako wnikliwy czytelnik chorwackiego czasopisma „Zenit”, byli zorientowani we współczesnym ruchu awangardowym, zachodnim, środkowoeuropejskim i wschodnim. Podejmowali polemikę z serbską i chorwacką figurą poety barbarogeniusza oraz z zenitystyczną koncepcją konstrukcji wiersza syntetyzującego warstwowo (rolady), a także z propozycjami rosyjskiego konstruktywizmu; np. Kosovel odrzucał ideę inżynierii dusz i matematyczne formuły Aleksieja Cziczerina, lecz zainteresowała go technika „gruzofikacji”. O ile kontakty 
z awangardą chorwacką i serbską były w Słowenii bezpośrednie, o tyle rosyjski konstruktywizm był znany pośrednio. Polska awangarda estetyczna, przeciwna w większości rewolucji rosyjskiej i temu, co działo się w Związku Radzieckim, nie interesowała kurierów (np. Iva Grahora) przynoszących stamtąd wieści. Choć polscy twórcy nazywali się artystami rewolucyjnymi, przewrotu dokonywali w sztuce.

\section{Bibliografia}

Artaud, A. (1978), Teatr i jego sobowtór (tłum. Jan Błoński), Wydawnictwa Artystyczne i Filmowe, Warszawa.

Barańczak, S. (1974), „Przekład artystyczny jako «samoistny» i «związany» obiekt interpretacji (na przykładzie niektórych polskich thumaczeń Gottfrieda Benna)", [w:] Jacek Baluch, red. $Z$ teorii i historii przektadu artystycznego, Wyd. UJ, Kraków, 47-74.

Białoszewski, M. (2004), Oporoka spečega (tłum. Primož Čučnik et al.), LUD Šerpa, Ljubljana.

Dialogi (1969). 5: 264-266.

Even-Zohar, I (2009), „Miejsce literatury thumaczonej w polisystemie literackim” (tłum. Magda Heydel), [w:] Piotr Bukowski, Magda Heydel, red. Wspótczesne teorie przekładu. Antologia, Znak, Kraków, 197-203.

Hermans, T. (2009), „Przekład, zadrażnienie i rezonans” (tłum. Magda Heydel), [w:] Piotr Bukowski, Magda Heydel, red. Wspótczesne teorie przekładu. Antologia, Znak, Kraków, 297-315.

Jarniewicz, J. (2002), „Tłumacz jako twórca kanonu”, [w:] Roman Lewicki, red. Przeklad-język-kultura, Wyd. UMCS, Lublin.

Jež, N. (2006), „«W świecie polskiego piśmiennictwa budzi się teraz nowe życie»", [w:] Romuald Cudak, red. Literatura polska w świecie. Zagadnienia recepcji i odbioru, Gnome, Katowice, 67-74.

Kosovel, S. (1977), Zbrano delo, Vol. 3, cz. 1, Anton Ocvirk, red., DZS, Ljubljana. Lefevere, A. (2009), „Ogórki Matki Courage” (thum. Agata Sadza), [w:] Piotr Bukowski, Magda Heydel, red. Wspótczesne teorie przekładu. Antologia, Znak, Kraków, 223-246.

Łapiński, Z. (2002), „Szkoła lwowsko-warszawska, Awangarda Krakowska, konstruktywizm łódzki (Kartka z dziejów naturalnych nowoczesności)", [w:] Stanisław Balbus, Edward Balcerzan, red. Stulecie Przybosia, Wyd. Naukowe UAM, Poznań, 15-26. 
Matuszewski, R., Stoberski, Z., Krakar, L., red. (1963), Poljska lirika dvajsetega stoletja, antologija (ttum. Lojze Krakar), DZS, Ljubljana.

Między Oryginałem a Przekładem (1999). 5: Na początku byt przekład, Kraków. Miłosz, C. (1982), Ziemia Ulro, PIW, Warszawa, 33-35 (pierwodruk: Paryż, Instytut Literacki, 1977).

Miłosz, C. (1990), Zaczynając od moich ulic, Wyd. Dolnośląskie, Wrocław, 122-136.

Paternu, B. et al., red. (2000), Prešernovi dnevi v Kranju, Mestna občina, Kranj, 261-270.

Peiper, T. (1972), Tędy. Nowe usta, Wyd. Literackie, Kraków.

Planinski vestnik (1978). 12: 771-772.

Przyboś, J. (1955), Najmniej słów, Wyd. Literackie, Kraków.

Šalamun-Biedrzycka, K. (1980), Poezja Antona Podbevška i Antona Vodnika w latach dwudziestych XX w. Zmiana wizji świata, Zakład Narodowy im. Ossolińskich, Wrocław.

Štefan, R. (1960), Poljska književnost, DZS, Ljubljana.

Štefan, R., red. (1999), Prošnja za srečne otoke. Antologija poljske ljubezenske lirike (tłum. Rozka Štefan), Didakta, Radovljica, 84, 92.

Štefan, R., Jež, N., red. (1992), Alarm. Poljska poezija 1939-1945 (tłum. Rozka Štefan, Tone Pretnar), Mladika, Ljubljana.

Tokarz, B. (2000), „«Gazele» France Prešerna a sonety odeskie Adama Mickiewicza", [w:] Boris Paternu et al., red. Prešernovi dnevi v Kranju, Mestna občina, Kranj, 261-270.

Tokarz, B. (2002), „Polskie thumaczenie Strefy Apollinaire'a w dialogu awangardowym", [w:] Piotr Fast, Katarzyna Żemła, red. Przekład w historii literatu$r y$, Śląsk, Katowice, 115-128.

Tokarz, B. (2004), Miedzy destrukcja a konstrukcją. O poezji Srečka Kosovela w kontekście konstruktywistycznym, Wyd. Uniwersytetu Śląskiego, Katowice.

Tokarz, B. (2016), Poezja Stanisława Barańczaka w przekładach stowiańskich, [w:] Romuald Cudak, Karolina Pospiszil, red. Literatura polska w świecie, t. 6: Barańczak. Postscriptum, Gnome, Katowice, 142-158.

Vodnik, F. (1963), „Rozka Štefan, Poljska književnost”, Sodobnost. 1/2: 169-170.

Vrečko, J. (1986), Srečko Kosovel. Slovenska zgodovinska avantgarda in zenitizem, Založba obzorja, Maribor.

Vrečko, J. (2011), Srečko Kosovel. Monografija, Založba ZRC, Ljubljana.

Wat, A. (1990), Mój wiek. Pamiętnik mówiony, cz. 1, Czytelnik, Warszawa, 26-27 (pierwodruk 1977). 


\section{STRESZCZENIE}

Awangardowość oznacza ten rodzaj prekursorstwa, który poprzedza jaką́s zasadniczą zmianę. Przekład może taką zmianę sprowokować w literaturze przyjmującej, prezentując utwory mające potencjał dokonania w niej zwrotu, albo może stać się przewrotem w sztuce tłumaczenia.

Awangardowa funkcja literatury polskiej w Słowenii jest rozmyta. Obecna jest w świadomości niektórych twórców, choć nie ujawniają oni tego w sposób eksplicytny. Nie można więc jej przekładom przypisać roli awangardowej w okresie międzywojennym, obfitującym w burzliwe przemiany sztuki europejskiej i nie tylko. Polska awangarda historyczna była dla czytelnika nieznana i taka nadal pozostała poezja jednej z centralnych grup poetyckich, Awangardy Krakowskiej. Przekłady prozy i dramatu awangardowego tamtego czasu są spóźnione, by taką funkcję spełniać, ponieważ ukazują się dopiero po latach siedemdziesiątych.

Słowa kluczowe: awangardowość, przekład, awangarda historyczna, mediacja, różnica

\section{SUMMARY}

\section{Translation in the Perspective of Avant-garde}

Avant-garde is a kind of precursor that precedes some fundamental change. Translation can provoke such a change in the host literature, presenting works that have the potential to make a turn in it, or it can become revolutionary in the art of translation.

The avant-garde function of Polish literature in Slovenia is fuzzy. It is present in the minds of some authors although they do not exhibit it in an explicit way. Therefore, it is not possible to assign its translations an avant-garde role in the interwar period, which abounded with stormy transformations of European art and not only. The Polish historical avantgarde was unknown to the reader, and the poetry of one of the central poetic groups, the Krakow Avant-Garde, has remained so. The translations of avant-garde prose and drama of that time are late to fulfill such a function because they only appeared after the 1970s.

Keywords: avant-garde, translation, historical avant-garde, mediation, difference 